\title{
Malaysian and Nigerian Foreign Policy in Comparative Perspective
}

\author{
Michael B. Aleyomi ${ }^{1}$ \\ Mohamad Zaini Abu Bakar² \\ ${ }^{1}$ Ph.D Candidate, Department of Political Science, School of Social Sciences, Universiti Sains Malaysia \\ Email: aleyomimike@yahoo.com \\ ${ }^{2}$ Professor (Madya), Department of Political Science and also the Deputy Dean (Academics), School of Social Sciences \\ Universiti Sains Malaysia
}

\section{Doi:10.5901/mjss.2015.v6n6s4p125}

\begin{abstract}
This study explores the nexus between Malaysian and Nigerian Foreign Policy by examining the personality traits of Mahathir, 1981-2003 and Obasanjo, 1999-2007 respectively. The overriding consideration of national interest and foreign policy of a country reflect keen perception of, and determined by, national leaders. The study examines the divergence and convergence in foreign policy making of the two personalities. Historical-descriptive approach was used as a method of data collection and analysis. Utilizing secondary data in testing their influence, the findings reveal that Obasanjo's idiosyncrasy has approximate similarity with Mahathir's on high level of understanding internal, regional, and international dynamics, and aligned strategic survival of their states with broader regional and global trends. While MFP consolidates the ideal principles of Mahathir, NFP experiences policy somersault. Given this scenario, the paper argues for a significant shift from Afro-centric to institutionalized Nigerian-centric policy thrust, if development must be genuinely experienced and sustained in Nigeria. Territorial defense, and security of live and property are the hallmarks for national survival cum development of any nation. In the circumstance, we consider periodic evaluation of national interests and specific bilateral security treaty in all ramifications as a highly useful and pivotal option.
\end{abstract}

Keywords: Leadership Traits; Foreign Policy; Development; Malaysia, and Nigeria.

\section{Introduction}

Foreign policy studies of developing countries in general have been either very narrow in their focus, such as based on the nonalignment theme, or comprehensive without being historically dynamic, and comparative without examining being inter continent in their analysis. Though some studies and efforts of the comparative scholars of foreign policy have focused primarily on the idiosyncrasies of the leaders of developing nations (which is also known as the Third World countries), yet, these studies have not completely addressed the deficiencies accrued to the question of development. Also, despite scholarly and popular works regarding the roles of actors in foreign policy making, there still little knowledge about how these actors shape or affect the public's foreign policy views. There is a dearth of studies exploring the construction of ideas on regionalism most especially on the issue of foreign policy that cut across Asia and Africa continents. Some countries under the classification of being "Third World" are making effort to develop while some, under the same category, seem not to yield positive value in terms of development. Can the level of success or otherwise of country's development be attributed to the personal skills and idiosyncrasies of the leaders when countries are comparatively juxtaposed? This, and some other questions, is what this paper seeks to address through the study of the content, sources and development across different issue-areas of Malaysian foreign policy vis-à-vis Nigerian foreign policy. These countries fall in the Third World category but of different continent. While Malaysia is of Asia continent, Nigeria is of Africa continent.

What constitutes national interests (through which foreign policy is extracted) and how these interests are made and implemented, as they affect the development or growth - political, economic and security - of the states, is problematic. The major concerns of states include security, development, and protection of their sovereignty, and characteristics that distinguished them from other countries and how to enhance their sustainability in the international system. Besides, the whole essence of international relations and drafting of foreign policy is that state interacts with other state, because state at the international system does not operate in isolation. In the study of international relations, domestic factors influence foreign policy decisions. It is pertinent however to investigate comparatively, these domestic 
exigencies which Campbell (1998) calls "institutionalized ideas", that are represented at the highest levels of the decision making structure in foreign policy decision outcomes. This being said, foreign policy of a nation is a diplomatic concept that explains the level of state's relations with other states outside boarder. Based on this fact, foreign policy needs to be active, reactive and proactive towards the aspirations of the citizenry, because the citizen's welfare is the first target in the diplomatic concentric circle (Adoba, 2014). In other words, states' actions towards foreign policy formulation and implementation have a telling effect on the image of the country and citizens wherever they resides. The overriding consideration of national interests and foreign policy of a country reflect keen perception of, and determined by, national leaders. Therefore, the functionality of foreign policy behooves the policy makers' ability. Hence, this study investigates the nexus between Malaysian and Nigerian Foreign Policy by examining the personality traits of Mahathir, 1981-2003 and Obasanjo, 1999-2007 respectively on foreign policy decision making.

Essentially, the perception of a country in the international community is attributed to competency or ineptitude in political leadership's skills in addressing economic, political and security challenges that may afflict the country (Goldstein and Pevehouse, 2010:103; Ogunbayo, 2011:28). The foreign policy of any country is premised on key concepts stemming from its own unique historical experience, its present level of achievement, its aspiration as a nation-state among the comity of nations, and its perceptions of national potential in relation to the opportunities and constraints arising from the character of the international system. The persistence of these long-term national interests and structural factors generally determine foreign policy making regardless of who holds political power. In other to frame up the study of foreign policy in general against the backdrop of Malaysia and Nigeria, a short critical historiographical review of the two countries' foreign policy vis-à-vis the personalities traits of Mahathir and Obasanjo is indispensable.

The choice of Malaysia and Nigeria makes the study fascinating and expedient because both countries share similar colonial history since they were both colonized by Britain and are members of the Commonwealth of Nations. While Malaysia got independence in 1957 Nigeria got independence in 1960. Both countries have common social cultural background, they are both heterogeneous states, the two countries are radically split along ethnic and religious lines with three major ethnic groups (the Malays, the Chinese, and the Indians in Malaysia, while the Yorubas, the Igbos, and the Hausas in Nigeria) and with existence of an elementary or basic knowledge of nationhood. They are also members of Organization of Islamic Cooperation (OIC). In terms of businesses and products, they are almost the same because whatever is produced in Malaysia the market is available in Nigeria. Both countries have been diplomatic friends and are members Developing-8 (D-8) an Organization for Economic Development Cooperation among eight (8) countries: Bangladesh, Egypt, Indonesia, Iran, Malaysia, Nigeria, Pakistan, and Turkey. The two personalities under review can also be said to have moved the foreign policy of their respective countries from traditional to modern foreign policy.

Malaysia and Nigeria bilateral relationship was formally established way back in 1965 when the first and the only Nigeria's Prime Minister, Alhaji Abubakar Tafawa Balewa, became a good and diplomatic friend of one of Malaysia's postindependence leaders and Father of Malaysia's independence Bapa Kemerdekaan, Tunku Abdul Rahman, who incidentally the first Malaysia's Prime Minister (Teik, 1996). Although Nigeria set up its Malaysia high commission in 1991, primarily to promote diplomatic relations between the Federal Republic of Nigeria and Malaysia and also with the mission of promoting trade and investments between the two countries and issuance of visa to nationals of Malaysia, wishing to visit Nigeria. Based on long historical and cultural ties, together with many common good and interests, both countries have intensive bilateral arrangements and have been enjoying warm and cordial relations. Nigeria has its High Commission in Kuala Lumpur while Malaysia has its High Commission in Abuja. Their relations are based on economic co-operation. Despite these historical and personal similarities, the two countries are of different stride in the level of development. This study attempts to painstakingly examine this phenomenon and postulate ways of achieving stable bilateral relations in all ramifications and enhance development most especially in Nigeria.

\section{Objectives and Methods}

There is a belief that foreign policy of any nation is not an illogical business rather it is systematic and organized process that operates through some laid down rules and regulations, which is expected to be impactful and acceptable (Effiong, 2012). Therefore, the objective of this study is to examine how these principles are made and implemented by the State or policymakers. This is with a view to differentiate changes and continuities, divergence and convergence in foreign policy making of Malaysia under Mahathir's and Nigeria under Obasanjo's regimes respectively. It bids to add to the existing knowledge, fills the gap that previous literature could not cover, and provides useful information to academics and public policy makers so as to provide succor for their intellectual curiosity and inquisitiveness on the pace of development of the two countries.

The paper adopts qualitative and descriptive methods of analysis drawn largely from secondary sources, which 
were sourced through library materials such as official document, books, journal articles, newspapers, and internets materials. The eligibility and inclusion criterion to integrate the qualitative approach in this study is due to its significant advantages. The use of qualitative data gathering method is more open to changes and refinement of research ideas as the study progresses. This implies that qualitative data gathering tools is highly flexible and analytical.

\section{Theoretical and Conceptual Analysis}

Foreign policy analyses have tended to focus on policy makers and leadership styles (Ajinde and Aleyomi, 2014). This factor may be defective in developed countries without demands for consideration of other salient elements, but leadership idiosyncrasy in foreign policy making is very relevant and indispensable in developing countries. Dealing with the issues of Foreign Policy Analysis, there is need of cognitive approaches which will help to explain the roles of foreign policy actors in decision making towards development or otherwise. These approaches have been in the crux of researchers on interstate actions. The ideas-oriented scholarship towards comparative study of status quo of the countries in the international system most especially the "Third World" has been considerably limited (see Adler, 2002; Houghton, 2007). This limitation is in part owing to the lacuna in the fields of International Relations, Comparative Politics, and Foreign Policy Analysis. To tackle the issues surrounding foreign policy analysis, there is need to apply cognitive approaches.

According to Oppermann and Spencer (2013), foreign policy analysis can be seen from two major cognitive approaches which are salience and metaphor analysis. It is cognitive because it is relating to thought processes of acquiring knowledge by the use of reasoning, intuition and perception. The issues relating to salience and metaphor are cognitively heuristics that address different aspects of foreign policy problems. The approaches complement each other with long pedigree due to their ability to making foreign policy. The foreign policy making and action of Mahathir and Obasanjo, like that of any other leaders, are matters of salience and metaphoric analysis and decisions (Adeniji, 2005; Oppermann \& Spencer, 2013). A rational leader engages in cost-benefit analysis of maximizing gains and minimizing losses in international politics. The concept of salience looks at the priming of issues in the foreign policy making while the concept of metaphors relate to the framing of these issues. In other words, the salience approach of foreign policy issues deals with critical and primary issues that foreign policy actors attend to while metaphor explains how actors structure these issues and outline them as policy options to be implemented without jeopardizing the national interests.

Like all theories, the cognitive approach has its own shortcomings as well. Ideational problems and cognitive dissonance as opined by Festinger in social psychology (Folarin, 2013) are some of the attached difficulty of the approach, cloaked in uncertainties, ranging from effect of events on the international scene on decision making and multiple goals of decision makers. Due to different aspects of human's (actors) cognition with tendency of been competitive or complimentary relationship to each other, the application of cognitive approaches to analyze foreign policy making is indispensable (Campbell, 1998). Certain factors impinge on decision makers' capacity to make decisions, such as the fact that most times decisions are reached in a group context, or put differently agreement is required before a decision is arrived at without proper priming and framing. Another significant problem to this approach is the difficulty of defining the issues that require decision makers' attention (Flanik, 2011). This is obvious as a result of lack of or delay of information, while some information available is most times inaccurate. Nigeria is facing the problem of ambiguity in defining what national interest is, hence, affect her goal selection. Cognitive approach to decision making model captures the essence of the arguments in the paper and will be the binoculars to look at the issues and scale to comparatively examine the decisions and actions of the two personalities under review and how these decisions have impacted on their individual countries.

Against this backdrop, it is pertinent to note that the contemporary situation of Malaysia and Nigeria is a fundamental example of decisions made in the past by the decision makers and the importance placed on the domestic environment in shaping the nation's foreign policy. Mahathir foreign policy is best explained within the overarching concern of national interest and development. He skillfully makes that argument in full awareness that this concern did not operate within a vacuum and hence his attention was on domestic, idiosyncratic (modernization) and external factors (Dhillon, 2009). His era underwent significant shifts in terms of direction, nature, substance, style and rhetoric. For Nigeria, the fundamental connection between economic capacity and the projection of continental leadership challenges in foreign policy is a recurrent dilemma. This is presently aggravated by external forces associated with globalization. Though the Obasanjo's foreign policy was also concerned on the national interest and attention drawn to domestic challenges, regional and continental affairs were seen to be more of priority. Obasanjo, cited in (Okolie, 2010), opines that "Nigeria cannot provide a credible leadership for West Africa in particular and Africa as a whole without a sustained effort to develop the appropriate structural foundation domestically, but Africa will always remain strategic to Nigeria's 
foreign policy". This statement is a clear indication that Nigeria foreign policy is traditionally established on, and still continues with its, Afrocentric foreign policy thrust.

A critical review of foreign policy literatures indicates that scholars are mutually consensual in their opinion, description, and definition on the concept (Heilbrunn, 2009; Eze, 2010; Saliu, 2013). The essence of any nation's foreign policy is intended to maximize the available opportunities and minimize the cost of domestic threats within and outsides its geographical boundaries. A fundamental concept in international relations that states invariably use as a tool of understanding as well as policy is the national interest. This concept is so basic to the pursuit of foreign policy that it is seldom defined, and usually taken for granted that statesmen, policy makers, entrepreneurs, and scholars have a common understanding of its meaning. When applied to foreign policy, the national interest of any state represents an aggregation of its goals and capabilities in relation to the goals and capabilities of other similar actors in the international system (Nathan, 1995). Hence, the National Interest of Malaysia and Nigeria, in this regards, necessarily reflect keen perception by the national leadership of the relationship between ideal (what is desirable) and reality (what is possible). It is this relationship or the ability to maintain a workable balance between these values of desirability and possibility that determines the nation's foreign policy analysis.

The link between domestic politics and foreign policy has been confirmed because foreign policy is a product of many domestic factors and forces to a very large extent (Rolenc, 2013). While foreign policy could be seen as the totality of all actions, decisions, and interactions between or among nation-states in the international system, national interests are actions, circumstances, and decisions regarded as benefitting a particular nation. National interests are basic goals or motivations that countries seek to achieve which undergird the diplomacy of the respective nations within the international system, foreign policy is an instrument, the calculated steps or methodology (actions or inactions) through which nations intend to achieve their goals outside its geographical boundaries (Harun, 2009; Agreen, 2014). Unfortunately however, literatures have shown in clear terms that National interest of a country is the interest of its leader. Policy makers most especially the head of government are the key determinant factors of what national interest is. Every vibrant foreign policy derives its strength from the domestic needs of the country and the populace. Internal political events usually have a lot of impact on foreign policy (Bulley, 2014), hence, the overriding consideration in foreign policy implementation is, and should, always based on the concept of national (masses) interest, Malaysia and Nigeria are no exception as the following discussion will demonstrate.

\section{Foreign Policy Decision-Making: The Divergence vis-à-vis the Convergence of Mahathir's and Obasanjo's Personalities Traits}

There is a leader in any government, who has the authority to make foreign policy. According to Kaarbo (2013), the uniqueness of these leaders shapes the state's foreign policy. Under these conditions, idiosyncrasies of a leader may shape what the state does, and this occurs frequently in country's foreign policy-making. The impact of personality on decision-making as it relates to foreign policy analysis is controversial. While Smith (2012) submits that it is mere fallacy to analyze and understand countries' foreign policy due to the leader's personality traits, but Echono (2013) counters Smith submission and opines that personality traits often affect foreign policy decision. The quality and effectiveness of a leader influence, either positively or otherwise, foreign policy decision making which will in turn brings development, if the personality traits contain good decision making skills and competence. Be that as it may, personality traits influence foreign policy analysis, when leaders possess good decisional latitude in domestic and external affairs. This is where complementary role of priming and framing foreign policy play a significant part. According to Magbadelo (2012), every regime has an understanding of what its historical mission in the country's economical and socio-political landscape was, and that perceived essence had often informed the regime's foreign policy experts on what the country's relations in the global society should be. There is no agreement among the international relations experts on what foreign policy thrust of a country should be in the extant literature but the onus of political decisions and country's relations in the international system rest on the political leaders of such country. It is expedient, however, to briefly examine what informed foreign policy making under the two regimes of Mahathir and Obasanjo in Malaysia and Nigeria respectively.

\subsection{The Foreign Policy and Personality Traits: Tun Dr. Mahathir Mohamad (1981-2003)}

Dr. Mahathir Mohamad became the fourth Malaysia's Prime Minister on July 16, 1981. He is described as a visionary, dictator, modernizer and anti-Western (Saravamuttu, 2010), but above all, Father of Development Bapa Pembangunan and a defender of 'Asian Values'. The foreign policy under his watch has been described as distinct among 'Third World' leaders in several ways. Teik (1996) admires Mahathir's vision and ideology of state intervention to restructure and 
industrialized Malaysia into Asia's 'Fifth Tiger' with an enigma of ideas on nationalism, capitalism, Islam, populism and authoritarianism which are the core of Mahathirism. The Malaysian foreign policy under Mahathir brought significant change to Malaysia and has been described as independent, active and pragmatic (Yusoff and Soltani, 2013). Mahathir's foreign policy thrust is best understood by focusing upon the interaction of his personal idiosyncrasy, pertinent domestic issues, and external factors that are relevant and significant to the country. The domestic elements during the Mahathir era are accorded a binocular look of focusing on ethnic integration, regime maintenance and national development, while the external variable encompasses regional and global events (Dhillon, 2009). His unrelenting efforts to move Malaysian foreign policy away from traditional stance (Harun, 2009), made Mahathir to often seen as the sole author of the country's foreign policy and father of modernization.

Malaysia is widely held as a great development success story among the third world countries. The motivation underpinning Malaysia's foreign policy under Mahathir's premiership is undisputable evidence to the contemporary status of Malaysia among the comity of 'developing' nations, in Asia and other continent. The driving force of Malaysian foreign policy under this period was concerned for national interests in the area of security and a search for acquisition of national wealth and development. The thought of Mahathir to transform and modernized Malaysia was summarily documented by Kershaw (1999:407) when he argues that Mahathir sees capitalism as the key to the country's liberation from determinism; his idea on religion conservatism brought Islam, interpreted to rationalize the work-ethic which capitalist success presupposes, while avoiding any hint of cultural hegemonism which would alienate non-Muslims; Mahathir's own populist relationship with the Malay masses and the shift from populism towards authoritarianism; and the post-1990 vision of developed-country status for Malaysian by 2020, alongside with final emergence of a 'one' Malaysian people are all embedded in Malaysian foreign policy under Mahathir administration. In reality, these encapsulated the contents of realism and idealism as well as constructing the policy to attain security, prosperity and wellbeing of all Malaysian citizens. Mahathir aspiration to galvanize the Malaysian nation to transcend its 'developing' status and join the league of the industrialized states was significant and his achievements were testament. His most typical prescription for international economic success and strategic credibility was advocated and formed an important theme of his political techniques with the introduction of "Look East Policy", a policy that had confrontation with the West by not so much in order to extract trade liberalization, favourable credit terms, technology transfer among others, to unify the different races of Malaysia through a shared conviction of external menace (Kershaw, 1999).

The foreign policy under Mahathir was premised on consistent, principled and pragmatic ways of managing National Interest, bearing in mind the limits and constraints prevailing in the domestic and international spheres. Mahathir believes on the need for a sound economic policy/orientation in order to be successful nation and gained the respect of other nations. He 'radically' shifted focus from political to economic through the public policy to build a self-confidence nation according to its own mould and targeted for economic growth and development to improve the quality of lives of the citizens (Jomo, 2001). Mahathir embarked on some strong hand decisions and grip on the country's affairs to sustain political stability, peace and security (Abdul-Hamid, 2010). The foreign policy postures, initiatives and outcomes, encompassed the country's security, economics, political and societal wants and needs in the fulfillment of its goals and aspirations to be a developed nation by 2020. It is a truism that any policy formulation and decision making would have the stamp of the leader, his interpretation of events and environments as he perceived them as well as his reactions towards them (Houghton, 2007).

Mahathir continued with the inherited policy of regionalism which serves as the cornerstone of Malaysia Foreign Policy since independence. Maintaining regionalism was a fundamental factor of the National Interest. The prerequisite for domestic economic growth and development was to see the region living in peace, security and stability with freedom and neutrality free from any major powers rivalry (Harun, 2009). The foreign policy postures, initiatives and outcomes, under Mahathir, had domestic relevance and international acceptance, which served the National Interest of Malaysia aligning it to the struggles against the injustices and unfairness in the international political system in all dimensions (Cantir and Kaarbo, 2012). As a player, Malaysia had an influencing role in the organizations of the South countries, such as the NAM, G15, (where Malaysia was one of the founding members). Malaysia was also one of the main backers of the South Centre, a body established as a secretariat for the South countries to champion the cause of the developing countries on issues of trade and the economy at the WTO in Geneva (Syed, 2014). Malaysia showcased itself during the Mahathir era as a model of a successful developing country and sustained a more tolerant and harmonious diverse society and was politically stable. Amidst economic contractions and lurid political battle between Mahathir and his erstwhile deputy - Anwar Ibrahim which put Malaysia into precarious situation of fears and apprehensions in 1998, Prime Minister Mahathir Mohamad was able to levitate the economy and revived consumer confidence, and convinced Malaysians that his capital-control gambit will work, boosting its chances of success (Appell, 1998; Muhamad, 2014).

The criticism pro-East and anti-West methodology of Mahathir is left undecided among foreign policy scholars both 
at the domestic and international levels (Abdul-Hamid, 2010; Moten, 2011). Mahathir has been labeled as anti-West and authoritarian especially in his international political posturing but his interpersonal relationships with some Western political and business leaders would indicate otherwise (Syed, 2014). By no means of justifying Mahathir's action toward the West, there were two observable sides of Mahathir. Firstly Mahathir in the defense of the national interest, he was essentially independent and uncompromising, and secondly in the economic policy and personal relationships he was a more pragmatist. His actions to some extend were very much driven by his view on the injustice and unfairness of the colonial era, and the international system. His actions arguably would have been to rearrange the international political, economics, security and societal systems to create a more balanced world order for the benefits of the developing and developed countries. Mahathir seemed to be a realist but at times showed an inclination towards idealism in foreign policy formulation and decision making.

\subsection{The Foreign Policy and Personality Traits: Chief Olusegun Obasanjo (1999-2007)}

The relationship and impact of any independent nation-state with other states, influences certain decisions that will directly or otherwise affect such state and others in the international system. The return to civil rule and the swearing in of a democratically elected president, Chief Olusegun Obasanjo, in May 29 1999, launched the country into a 'new phase' of external relations (Okpokpo, 2000). Since independence, Africa has been the centerpiece for Nigeria's foreign policy with emphasis on emancipations, development and unity of Africans both within and outside the continent, and political and socio-cultural liberation of African states (Ajinde and Aleyomi, 2014:491-531). Be that as it may, the major principle influencing Nigeria's foreign policy can be summarily put as: the unsuccessful non-alignment, as Nigeria unabashedly titled to the west; multilateral diplomacy; and afrocentric policy thrust.

The foundation and the line of direction of Nigeria foreign policy when President Olusegun Obasanjo took over power in 1999 was in apprehensive position and shrouded in uncertainty. Politically, the structures were very fragile and destabilizing as a result of long date of military rule in the country. The economic was in a bad shape with financial crunch, unemployment and high level of poverty (Fayomi, Chidozie and Ajayi, 2015). Another contradictions and apprehension to the emergence of Chief Obasanjo was his military background and personality traits. This was coupled with regional politics as he, a Yoruba man who did not enjoy popular support from his tribe, but was seen from many quarters to have been sponsored by the Northerners hence, he will be loyal to them at the expense of national interest. All these challenges notwithstanding, his foreign policy option was rated high. His level of preparedness and foreign relations, through his world tour and subsequent achievements that addressed some domestic problems was crystal clear and a testament to his personality traits (Oviasogie and Shodipo, 2013).

In a bid to align with the gale of globalization and rid the vestiges of development crises, Obasanjo's regime was pious to address this, not only in Nigeria but also at the continental level. There were concerted efforts of Nigeria with some other Africa countries to the formation of some organizations (Saliu, 2006). Also, Nigeria was a founding member and leader of the G-15, G77 (Group of 77) and Non-Aligned Movement. During Obasanjo's administration, Nigeria faced a lot of power tussle in the African continent as South Africa, Libya and Nigeria were contending as to who lead Africa despite all the efforts by Nigeria to combat the economic challenge in Africa continent. Due to his sense of seriousness to issues of national transformation, Obasanjo jumped an 'excusable' protocol and performed the role of the foreign affairs minister. He was undeterred by the fact that the headquarters and chair position of the AU went to South Africa, a situation which many scholars regarded as the beginning of Nigeria's less leading role in the continent. There is no disputing the fact that the leading role of Nigeria given her enormous resources in Africa is indispensable within the continent. Perhaps, this act disabused the mind of some Africa countries mostly the Francophone speaking which view Nigeria as a continental imperialist.

At the Domestic level, Obasanjo's foreign policy reinvigorated the national image on corruption and the perception that Nigeria is a dumping ground of fake drugs. He tried to address the issue of corruption through the introduction of anti corruption bill. The successful passage of this bill established Independent Corrupt Practice and Other Related Offences Commission (ICPC) and the Economic and Financial Crimes Commission (EFCC) to fight any corrupt act in the system. These institutions performed creditably well during the Obasanjo administration (Oviasogie and Shodipo, 2013). The successes recorded as a result of the above established institutions created conducive environments that encouraged foreign investors. The increase in Foreign Direct Investments (FDI) resuscitated the ailing economy the military bequeathed to the country in 1999 and reintegrates Nigeria into the global economy. Obasanjo's administration enhanced infrastructural restoration like in roads, energy, and telecommunications amongst others. One of his greatest achievements was in the areas of telecommunication (and many other sectors like National Electricity Power Authority NEPA) by allowing competition in the sector. This effort allows more than one control of market supply, especially in 
NITEL (Adeniji, 2005; Zaki, 2011).

As laudable this was, Obasanjo's administration had noticeable characteristics of authoritarian tendencies of the military rule a syndrome oppressive and undemocratic behaviour that negates rule of law. Due to this personality traits and obvious challenges Obasanjo had with the National Assembly, Oviasogie and Shodipo (2013), accuse him of being despotic. Bogus spending on regional and continental peacekeeping, precipitate diplomatic shuttles, sundry international conferences and other mediatory endeavours than its allocation to the missions without sufficient proof that it had explored other cost efficient options are all testaments. Besides, the foreign policy under Obasanjo failed, in practical terms, to harness the all-inclusiveness of the centre-piece and the principle of reciprocity embedded in the economic determinism school of thought to create for Nigeria a vibrant, proactive and responsive foreign policy without at the same time giving the country the illusory great power status. For the ordinary Nigerian, concentric foreign policy does not make any meaning if it cannot be adjudged as beneficial to the extent at which his quality of life is affected at both the short and long run.

\subsection{The Foreign Policy under Mahathir and Obasanjo Administrations: Convergence and Divergence}

The foreign policy behaviour under the two leaders in their respective countries had national interest as the major goal and their personality played significant role in maintaining foreign relations as enshrined in the national interest. They embarked on decisions and grip on the country's affairs to sustain economic reform and development, political stability, peace and territorial security. Both leaders were very active while in office towards the attainment of the national interest and quality foreign policy goals. They both applied cognitive approach to analyze their foreign policy. They were both indignant to policies that counterproductive. At various instances, these two leaders have successfully displayed these personalities' traits in making foreign policy decisions. They applied the principle of 'carrot and stick' in dealing with issues, though they are more nationalistic and more distrustful, but some of their actions indicated that they have to deal with the nature of the international system and exigencies, because international politics has influence on domestic decisions. Therefore, foreign policy decisions attest to the ability of leaders to understand and address not only the domestic exigencies but also manage the pressures associating with the international system. This effort, though not a new idea was intensified under the reviewed administrations of Mahathir and Obasanjo.

Be that as it may, there are discrepancies and clash of interest between what is supposed to be an individual (leader) interest and national interest. The perception of Mahathir towards the West, not minding his justification, had some telling effects on the country. Nigeria under Obasanjo did not hold any 'unfriendly' relations with any country of the world. While Malaysia embrace continuity and is building on significant foundation laid by Mahathir in the governing structure to keep its development status, Nigeria is facing significant pressures for reform mostly on the issues that affect economy (though now the largest economy in Africa) and foreign reserve. Some of the reasons to this set back are the global economic meltdown in 2008-2009 and leadership failure to diversified economy. A competitive export and diversified economy is not vulnerable to external shocks. This helped Malaysia not to significantly feel the global economic meltdown unlike Nigeria's economy whose growth has been mostly driven by oil, which represented 95 percent of export growth.

While the Malaysian foreign policy is experiencing relative development due to continuity in most of Mahathir's foreign policy ideology, post-2007 administrations have failed to consolidate on the gains of Obasanjo's foreign policy decisions that would have accrued from the "diligent application" of the constructive and beneficial foreign policy. Policy summersault has made the country's foreign policy towards economic development not well-articulated. The biggest problem with the performance of Nigerian leaders is their inability to be specific on what they want to achieve and have them prioritized. Nigerian leaders generally come into office with an all-conquering aura to solve all Nigerian problems at a time thereby end up in doing everything but completing nothing. This is one of the reasons for Nigeria's development crises. The mismanagement of Boko Haram crisis which escalated into insurgency and terrorist group is testament to unfocused leadership in Nigeria.

\section{Conclusion}

This study has shown the effect of personal idiosyncrasies in foreign policy making. The paper has also identified the changes in internal and external politics as they affect foreign policy analysis thereby suggests that both internal and external factors must be properly harmonized for effective formulation and execution of foreign policy. The formulation of foreign policy of any state is the virtual prerogative of national leaders. The various foreign policy postures, initiatives, traits and outcomes during the Mahathir's and Obasanjo's eras were shaped and influenced by the national interest, with 
change and continuity. As noted earlier, the choice of Mahathir and Obasanjo examines the personality role of leaders, through a qualitative and descriptive analysis, in foreign policy making most especially in the third world countries. The leaders' idiosyncrasies determine the development of the countries interstate relations, and how they twine with the national interest.

During the era of Mahathir, he was chiefly not deterred by external and domestic political pressure in other to swiftly redirect the country's foreign policy. His values and perceptions toward the development of Malaysia locally and reengineering its image internationally was decisive impact upon an institutionalized policy, through which pattern of decision-making, communication and influence correspond closely to formally defined roles and relationships that exist within the country vis-à-vis her engagements with other comity of nations. The level of 'radical' development Malaysia has attained today is attributable to Mahathir regime's decision-making process and personality traits to domesticate development. Given this scenario, we recommend that Nigeria should embrace a significant swift from Afrocentric to an institutionalized Nigerian-centric policy thrust (where the interest of the state and the citizenry is paramount) if development must be genuinely experienced and sustained in Nigeria. Besides, territorial defense, and security of live and property are the hallmarks for national survival strategy and development of any nation. Therefore, we consider periodic evaluation of national interest and specific bilateral or multilateral security treaty in all ramifications as a highly useful and pivotal option. Security diplomacy needs reassessment by the two governments in other to respond to changes and update their security apparatus to meet the international standard and make it a core foreign policy tool.

\section{References}

Abdul-Hamid, A. F. (2010). Politically Engaged Muslims in Malaysia in the Era of Abdullah Ahmed Badawi (2003-2009), Asian Journal of Political Science, 18(2):154-176

Adeniji, J. (2005). Cost and Dividends of Foreign Policy, Abuja: The presidential Advisory Council on International Relations

Adler, E. (2002). Constructivism and International Relations, in Walter, C. et al (eds.) Handbook of International Relations, Beverly Hills: Sage Publications

Adoba, I. (2014) Nigeria's Role in the Leadership of Africa: A Foreign Policy Perspective, http://www.academia.edu/10314154, Retrieved February 27, 2015.

Agreen, J. I. (2010) The Problematic of Redefining Nigeria's National Interest in the Contest, http://www.pointblanknews.com/Articles/ artopn2675.html, Retrieved April 22, 2014

Ajinde, O. \& Aleyomi, M. B. (2014). Nigeria's Foreign Policy, 1960-2014: The Problems and Prospects, in Ajayi, R., \& Joseph O. Fashagba (eds.) Understanding Government and Politics in Nigeria, Omu-Aran: Landmark University Press, pp. 491-531

Appell, D. (1998). Malaysian policy has yet to Yield Result: Mahathir's Bold Initiative to Revive Economy Draw Keen Scrutiny, The Asian Wall Street Journal, Vol. 1.

Bulley, D. (2014). Foreign Policy as Ethics: Toward a Re-Evaluation of Values, Foreign Policy Analysis, 10(2):165-180

Campbell, J. (1998). Institutional Analysis and the Role of Ideas in political Economy, Theory and Society, 27(3):377-409

Cantir, C. \& Kaarbo, J. (2012). Contested Roles and Domestic Politics: Reflections on Role Theory in Foreign policy Analysis and IR Theory, Foreign Policy Analysis, 8:5-24

Dhillon, K. S. (2009). Malaysian Foreign policy in the Mahathir Era, 1981-2013: Dilemmas of Development. Singapore: NUS Press

Echono, A. (2013). Goodluck Jonathan: Understanding the Psychology of Leadership, The Lawyers Chronicle, November 19. http://thelawyerschronicle.com/goodluck-jonathan-understanding-the-psychology-of-leadership/ Accessed May 13, 2015

Effiong, J. (2012). Reflections on Nigeria's Foreign Policy, Journal of Social and Psychological Science, Oxford Mosaic Publications, (5) $1,25-60$

Eze, O.C. (2010). Interrogating the 'National Interest' in Nigeria's Foreign Policy, in: Osita C. Eze (ed.) Beyond 50 Years of Nigeria's Foreign Policy: Issues, Challenges and Prospects, Lagos, Nigeria Institute of International Affairs, pp. 79-92

Fayomi, O. O., Chidozie, F. C., \& Ajayi, L. A. (2015). Nigeria's National Image and Her Foreign Policy: An Exploratory Approach. Open Journal of Political Science, 5, 180-196. http://dx.doi.org/10.4236/ojps.2015.53019

Flanik, W. (2011). Bringing FPA Back Home: Cognition, Constructivism, and Conceptual Metaphor, Foreign Policy Analysis, 7(4):423446

Folarin, S. F. (2013). Nigeria and the Dilemma of Global Relevance: Foreign Policy under Military Dictatorship (1993-1999), Covenant University Journal of Politics and International Affairs, 1(1):21-47

Goldstein, J. S., \& Pevehouse, J. C. (2010). International Relations, Ninth Edition, New York: Longman.

Harun, R. (2009). In Pursuit of National Interest: Change and Continuity in Malaysia's Foreign Policy Towards the Middle East. International Journal of West Asian Studies, 1:23-38

Heilbrunn, H. (2009). Foreign Policy in terms of Changing Domestic Coalitions and Political Factions, A Paper Delivered at International Seminar on Foreign Policies and New Directions for International Politics, Lagos: Sheraton Hotels, May 6.

Houghton, D. P. (2012). Reinvigorating the Study of Foreign policy Decision-making: Toward a Constructivist Approach, Foreign Policy Analysis, 3(1):24-45

Jomo, K. S. (2001). Malaysian Eclipse: Economic Crisis and Recovery. London: Zed Books 
Kaarbo, J. (2013). Coalition Politics and Cabinet Decision Making: A Comparative Analysis of Foreign Policy Choices. Ann Arbor: The University of Michigan Press

Kershaw, R. (1999). Review of Khoo Boo Teik 'Paradoxes of Mahathirism: An Intellectual Biography of Mahathir Mohamad', Bulletin of the School of Oriental and African Studies, 62(2):407-408. Doi:10.1017/s0041977x00017407.

Magbadelo, J. O. (2012). Review of Bola A. Akinterinwa 'Nigeria's Citizen Diplomacy: Theoretical Genesis and Empirical Exegesis'. Journal of Third World Studies, 29(1):326-328

Moten, A. (2011). Review of Johan Saravanamuttu 'Malaysia's Foreign Policy, the First Fifty Years: Alignment, Neutralism, Islamism', Intellectual Discourse, 19:307-311

Muhamad, A. F. (2014). The Struggle for Recognition in Foreign Policy: Malaysia under Mahathir, 1981-2003, A Research Thesis submitted to London School of Economics and Political Science. London: ProQuest LLC

Nathan, K. S. (1995). Vision 2020 and Malaysian Foreign policy; Strategic Evolution and the Mahathir Impact, Southeast Asian Affairs, Institute of Southeast Asian Studies (ISEAS) pp. 220-237

Ogunbayo, M. (2011). Our Best Foreign Policy Option, News Watch, June 6, pp. 28-29.

Okolie, A. M. (2010). Economic Diplomacy and the Conduct of Nigeria's Foreign Policy under Obasanjo's Administration, Nigerian Journal of International Affairs (NJIA), 36, 129-148

Okpokpo, E. (2000). The Challenges facing Nigeria's Foreign Policy in the Next Millennium, African Studies Quarterly, 3(3):31-36

Oppermann, K \& Spencer, A. (2013). Thinking Alike? Salience and Metaphor Analysis as Cognitive Approaches to Foreign Policy Analysis, Foreign Policy Analysis, 9(1):39-56

Oviasogie, F. O. \& Shodipo, A. O. (2013). Personality, Foreign Policy and National Transformation: An Assessment of the Olusegun Obasanjo's Administration (1999-2007). Covenant University Journal of Politics and International Affairs, 1(2):192-212

Rolenc, J. M. (2013) The Relevance of Neutrality in Contemporary International Relations. Working Papers, 2:1-20.

Saliu, H. A. (2006). Essays of Contemporary Nigerian Foreign Policy, Ibadan: Vintage Publisher

Saliu, H. A. (2013). "Foreign Policy", in: Saliu, H.A. and F.A. Aremu (eds.) Introduction to International Relations, Ibadan: College Press \& Publishers Limited

Saravanamuttu, J. (2010a). "Encounter of Muslim Politics in Malaysia", in J. Saravanamuttu (ed.), Islam and Politics of Southeast Asia, London and New York: Routledge, pp. 85-105

Smith, C. (2012). Personality in Foreign Policy Decision-Making, E-International Relations Students, October 16, http://www.eir.info/2012/10/16/personality-in-foreign-policy-decision-making/ Accessed May 1, 2015

Syed, H. A. (2014). The Foreign Policy of Malaysia under Mahathir: 1981-2003. June 6, http://syedhamidalbar44.blogspot.com/2014/06/ the-foreign-policy-of-malaysia-under.html Accessed May 10, 2015

Teik, K. B. (1996). Paradoxes of Mahathirism: An Intellectual Biography of Mahathir Mohamad. Kuala Lumpur: Oxford University Press

Yusoff, M. A. \& Soltani, F. (2013). Replicating of Domestic Security Policy in Malaysian Foreign Policy, Asian Social Science, 9(2):115120

Zaki, B. M. (2011). Nigeria: Economic Diplomacy and Country's Foreign Policy. Daily Trust, August 9, http://www.allafrica.com/stories/ 20110809352.html. Accessed May 13, 2015. 